\title{
Practical Discussion of Dialogue-based Teaching Model in College English Teaching
}

\author{
Caiyun, Zhang \\ School of Foreign Languages \\ Yan'an University \\ Yan'an, Shaanxi, 716000
}

\begin{abstract}
This paper is to discuss the dialogue-based teaching model in College English teaching. Generally, there are some common types of dialogue teaching-Teacher-Student Dialogue, Student-Text Dialogue, Teacher-Text Dialogue, Student-Student Dialogue, Teacher's Self-dialogue and Students' Self-dialogue. To arouse the interest of the college students to learn English better and to make the dialogue-based teaching produce better effects in the practice, the author of this paper comes up with three strategies-building a dialogue atmosphere of trust, honesty, democracy and harmony, setting participatory, challenging, appropriate and open dialogue topic, and creating more opportunities for student-student dialogue and teacher-student dialogue. These strategies make the dialogue-based teaching very different from the traditional ones. They set a free and open environment for college students to participate in English class and foster their initiative to acquire both English language and its culture.
\end{abstract}

Keywords-College English Teaching, Dialogue-based Teaching Mode, Connotation, Strategy

\section{INTRODUCTION}

English is important to all the majors in university, and it has been clearly pointed out in the new curriculum standards that students need to have good command of speaking and writing English. But in the actual teaching situation, the students' ability to apply is far from enough to meet the requirements of modern education and teaching. Students' English is not fluent in communication with foreign friends and teachers, making it hard to share values, emotions, experience, etc. This shows the importance, necessity and urgency to introduce dialogue-based teaching model. The traditional teaching mode makes it difficult to show the students' subject status. The teacher still controls the classroom. It plays a serious impact and constraints to the students' confidence and ability. Naturally there is no equal dialogue between students and the teacher, and the teaching objectives of college English is unable to be achieved. We will explore the dialogue-based teaching model below to provide the basis for the late English teaching.

\section{Connotation of Dialogue-BASEd Teaching Model}

Paulo Freire is the representative of the introduction of dialogue into the teaching. He pointed out that as one of the principles of education, dialogue contributes to the equal knowledge sharing and exchange between teacher and students.
This is a challenge to the subjective cognition, stereotypes and prejudices of learning essence, knowledge essence and teacherstudent relationship. However, Martin Buber pointed out that the dialogue-based teaching is not limited to teaching and learning, but subordinates to the "I-You" relationship. In the teaching process, dialogue-based teaching is the embodiment of principle and spirit of dialogue. In such teaching situation, the existence form of teacher and students is unique and holistic, and equal in status. It is based on trust and respect. It is communication and dialogue based on their own creativity and individual understanding when exploring problems, and will eventually reach a tacit agreement. That is to say that dialoguebased teaching is a teaching mode with the goal of creativity and humanistic teaching.

\section{SPECIFIC TYPE OF DIALOGUE-BASED TEACHING IN COLLEGE ENGLISH}

Six types of dialogue-based teaching in College English will be introduced below. They play a very important role in college English teaching.

\section{A. Teacher-Student Dialogue}

It refers to that teacher and students participate in teaching together, listen to each other, accept, accommodate, attract and share with each other, with mutual acceptance in spirit and interaction $^{[1]}$. The teaching model respects the spiritual dialogue and communication relation, changes the traditional conquering and cramming way of teaching, allowing teacher and students to open their hearts, talk and listen to each other's spiritual world. Conduct classroom teaching in a way of dialogue and understanding, and share the meaning of learning. The process helps to integrate the values of teacher and students, and contributes to the intersection and overlap of cognition, experience and knowledge.

\section{B. Student-Text Dialogue}

It is a process for students to criticize and understand texts. In teaching, textbook is an important basis of students' learning. In the process of student-text dialogue, it completely replaces the traditional repetition, memory and understanding, let students become the subjects of learning, form individual perception, and make a careful and detailed analysis of the text, so as to change the traditional teaching situation. For example, students find some implied sentences when preparing Titanic before class, such as "Should not any self-respecting modern 
person, let along feminist, object to it as insulting to women?". Through this sentence, we found that as a woman, the author opposed the traditional view of "lady first". This is the background information and content summary of the article, helping students grasp the intention of the article. In addition, we can also let students think about the intention of quoting this sentence and its expression, so as to deepen students' understanding of the content of the article.

\section{Teacher-Text Dialogue}

The process helps the teacher to deepen his understanding of the text through his own professional knowledge, ideas, skills and knowledge background. It has two specific forms, namely understand the text and feel the author's feeling from the perspective of the author; at the same time, dig into the practical significance of the text and combine it with the reality to promote the comprehension of the text. The process contributes to the formation of new ideas and significance. For example, when talking about what causes the Titanic shipwreck, the text discusses the traditional concept of "ladies first", and describes the location, time, and background of the Titanic. But in order to understand the history and social status of women in 1912, the teacher needs to search the relevant materials and show the relevant information to students in the classroom. "Chicken is only egg's way" is one of the stories mentioned in the text. It is a saying of the genetics. When explaining it, the teacher must tell students the source of the saying in advance, and analyze why it is quoted, at the same time analyze its context combining the whole text. In addition, the teacher should make more preparation for the lesson for possible questions that students may ask, and sort out the purpose of writing, intention of expression and message it wants to convey.

\section{Student-Student Dialogue}

Communication and dialogue between students contribute to the improvement of learning results ${ }^{[2]}$. At the same time, it promotes the collision and exchange of individual thinking of students, and helps them find their own deficiencies, while digest and understand students' point of view and construct complete English knowledge structure. It includes three specific forms: First, discuss the content of the text according to their own understanding and speak out different views to form knowledge collision. Student-student communication contributes to emotional expression and knowledge reserve, increases English verbal expression ability, further promoting the improvement of learning results. Second, set up teach groups to carry out research-style teaching activities and continuously absorb new skills and ideas. Third, carry out debate, performances and other learning activities, help students sort out knowledge in advance and develop good learning habits, promoting the gradual increase in the amount of knowledge reserves to use English to communicate.

\section{E. Teacher's Self-dialogue}

The process can help to reflect on the teaching process. Only by constantly reflecting on the handling of emergencies, understanding of knowledge and accumulating experience, can we promote the continuous improvement of teaching ability, and then analyze the knowledge in depth.

\section{F. Students' Self-dialogue}

The process helps students to understand their own shortcomings and clarify their own perplexities, continuously stimulating and tapping their potential. The college English dialogue-based teaching emphasizes the rationalization, habituation, self-conscious and deep-rooted rational dialogue and self-equality.

These teaching methods are very important in College English teaching, but they are difficult to be put in practice effectively. So, to make these dialogue-based teaching methods produce better effects in the practice, it is necessary to propose some strategies to construct a better dialogue-based teaching mode.

\section{Strategy to Construct College English Dialogue- BASED TEACHING MODE}

\section{A. Build a Dialogue Atmosphere of Trust, Honesty, Democracy and Harmony}

Building a dialogue atmosphere of trust, honesty, democracy and harmony is to change the traditional teaching process which regards teacher and textbook as the subject, and let students become the master of learning. At the same time, teacher-student relationship is no longer the indoctrination of knowledge, but become of dialogism. Replace standard response in traditional class with intense discussion between students or between teacher and students. And let students actively participate in teaching activities and express their own unique experiences, insights and understandings. Help students find errors through equal dialogue, and open their heart to trust and communicate with each other, building a harmonious classroom.

\section{B. Set participatory, Challenging, Appropriate and Open Dialogue Topic}

Topic, speaker and listener are elements of dialogue ${ }^{[3]}$. In order to improve the effectiveness of college English teaching, it is necessary to increase the students' participation. Therefore, in the topic selection, the teacher must combine social hotspots, students' life and its text, and take full account of students' cognitive level and physical and mental development characteristics, so as to set participatory, challenging, appropriate and open dialogue topics, making sure that the topic can meet the students' psychology to seek marvels, difference and innovation and maximumly stimulating students' desire to express and speak while ensuring that students have something to say.

\section{Create More Opportunities for Student-Student Dialogue and Teacher-Student Dialogue}

The students' thoughts are like spring water. Once opened, they will emerge continuously, and increase students' desire to perform $^{[4]}$. However, in the actual teaching activities, teachers often become the main body of teaching, making it difficult for students to express and develop their personalized thought. It 
further suppresses their inner enthusiasm to express and ask questions. Over time, students' excitement will run out and become silent and do not love thinking. Therefore, the teacher must create more opportunities for student-student dialogue and teacher-student dialogue, let students become the master of learning and take the initiative to express themselves. For introverted, timid students who lack self-confidence, the teacher should strengthen the encouragement and observation, give them performance opportunities timely, and let them gradually participate in the discussion of problems, gradually increasing students' language output and their psychological sense of security.

\section{CONCLUSION}

Through the above discussion, we know that in the college English teaching, dialogue-based teaching mode is a new type of means. It is very different from the traditional teaching mode. Therefore in the process, the teacher must strengthen the training of their own quality, and build a dialogue atmosphere of trust, sincerity, democracy and harmony, set participatory, challenging, appropriate and open dialogue topics and create dialogue opportunities based on that, promoting the continuous enhancement of learning enthusiasm and initiative of college students. In addition, the teacher and students must also flexibly master the modes of student-student dialogue, teacherstudent dialogue, student-text dialogue, teacher-text dialogue, teacher's self-dialogue and students' self-dialogue, and flexibly apply them in the teaching process, so as to lay a solid foundation for the carrying out of teaching activities and promote the improvement of teaching effectiveness to achieve the new curriculum standards.

\section{REFERENCES}

[1] Lan Liangmin. College English "Dialogue-based" Teaching Model Exploration [J]. Education for Chinese After-school(Theory), 2007, $10: 39+93$.

[2] Wang Ying. College English Class Dialogue-based Teaching Mode Discussion [J]. Educator(higher education forum), 2014, 03:106-107.

[3] Tan Shanshan. Main Model Analysis of College English "Dialoguebased Teaching"[J]. Manager' Journal, 2013, 12:348.

[4] Ni Laicheng. "Dialogue-based" College English Teaching Model Construction $[\mathrm{J}]$. Huaiyin Normal University Educational Science Forum, 2010, Z2:69-71. 